\title{
PELATIHAN KEWIRAUSAHAAN DALAM ERA NEW NORMAL KEPADA KARYAWAN PT MANDIRI UTAMA RUSLIM DI TANGERANG
}

\author{
Andi Wijaya \\ Program Studi Manajemen, Universitas Tarumanagara Jakarta \\ Surel: andiw@fe.untar.ac.id
}

\begin{abstract}
The COVID-19 pandemic that occurred in Indonesia was an unprecedented disaster. This catastrophic condition occurs almost all over the world which has a big impact on the economy. DKI Jakarta Province as the nation's capital has become the epicenter or center for the spread of the virus. The current economic condition of society requires everyone to "survive". This community service has presented an entrepreneurship training activity for PT Mandiri Utama Ruslim employees who are affected by this pandemic condition so that they prepare themselves to start their business. The activity was carried out in the form of a webinar on entrepreneurship to prepare employees in the COVID-19 pandemic situation.This PKM program is in the form of entrepreneurship training in the New Normal Era with employees of PT Mandiri Utama Ruslim in Tangerang. Tarumanagara University as an entrepreneur campus that helps provide funds for the implementation of this community service activity.
\end{abstract}

Keywords: entrepreneurship, entrepreneur, pandemic

\begin{abstract}
ABSTRAK
Pandemi COVID-19 yang terjadi di Indonesia merupakan bencana yang tidak pernah diduga sebelumnya. Kondisi bencana ini terjadi hampir di seluruh dunia yang membawa dampak besar bagi perekonomian. Provinsi DKI Jakarta sebagai ibukota negara telah menjadi episentrum atau pusat bagi penyebaran virus tersebut. Kondisi perekonomian masyarakat sekarang ini menuntut tiap orang untuk "bertahan hidup". Pengabdian masyarakat ini telah menghadirkan suatu kegiatan pelatihan kewirausahaan bagi karyawan PT Mandiri Utama Ruslim yang terdampak akan kondisi pandemik ini agar mereka mempersiapkan diri untuk memulai usahanya. Kegiatan dilakukan berupa webinar tentang kewirausahaan untuk mempersiapkan para karyawan dalam situasi pandemi COVID-19.

Program PKM ini berupa Pelatihan kewirausahaan dalam Era New Normal dengan kepada karyawan PT Mandiri Utama Ruslim di Tangerang. Universitas Tarumanagara sebagai kampus entrepreneur yang membantu penyediaan dana demi terselenggaranya kegiatan pengabdian masyarakat ini.
\end{abstract}

Kata Kunci: kewirausahaan, wirausaha, pandemic

\section{PENDAHULUAN}

Pemberlakukan kebijakan untuk melakukan pembatasan sosial di wilayah DKI Jakarta, memberikan dampak berupa melemahnya roda perekonomian khususnya di tingkat keluarga pada lapisan masyarakat kecil dan menengah. Atas kondisi tersebut, maka diperlukan upaya untuk memulihkan kondisi ekonomi keluarga bilamana pandemi COVID-19 ini berakhir. Implementasi program kegiatan untuk memecahkan masalah, adalah pemberian pengetahuan dan perkembangan bisnis secara online, analisis tentang pertumbuhan pengguna internet dan pengguna smartphone sehingga para peserta mampu menjadi praktisi technopreneur. Menurut Mopangga (2015), technopreneur adalah entrepreneur zaman baru yang berminat pada teknologi, kreatif, inovatif, dinamis, berani berbeda serta mengambil jalur yang belum dieksplorasi dan sangat bersemangat dengan pekerjaannya. Menurut Marti'ah (2017), terdapat perbedaan antara entrepreneurship biasa dan technopreneurship (technology entrepreneurship). Technology entrepreneurship fokus pada teknologi yang berfungsi sesuai kebutuhan target pelanggan dan teknologi tersebut dapat dijual dengan mendapatkan keuntungan (profit). Entrepreneurship umumnya berhubungan dengan bagian yang kedua, yakni menjual dengan mendapatkan profit. Dampak positif dari hadirnya media sosial adalah kemudahan interaksi, memperluas hubungan relasi, tidak adanya lagi batasan ruang dan waktu, serta penyebaran informasi yang cepat. Kewirausahaan memiliki peran penting dalam memajukan perekonomian suatu negara, sehingga diharapkan setiap warga negara harus memiliki niat untuk 
berwirausaha. Proses kewirausahaan menuntut kemauan untuk mengambil risiko dengan penuh perhitungan sehingga dapat mengatasi rintangan untuk mencapai kesuksesan yang diharapkan. Untuk mengembangkan usaha baru, penting untuk mamahami tentang apa yang membuat seseorang menjadi wirausaha.

Hal ini disebabkan fakta bahwa kewirausahaan merupakan proses kompleks yang melibatkan kognisi kewirausahaan dan tindakan kewirausahaan. Kewirausahaan juga merupakan perilaku yang disengaja dan terencana. Oleh karena itu, penting untuk meneliti lebih lanjut niat berwirausaha pada kaum muda. Menurut Ajzen (2020) kewirausahaan sebagai persepsi pribadi terhadap nilai, manfaat dan kesukaan dari kewirausahaan yang mempengaruhi niat mereka untuk memasuki area bisnis baru. Seorag individu memiliki sikap yang berbeda dalam menghadapi sesuatu. Penelitian telah menemukan bahwa sikap wirausaha dipengaruhi oleh beberapa faktor secara internal maupun eksternal yang membentuk perilaku. Sikap kewirausahaan tersebut dapat mendorong seseorang untuk menjadi wirausahawan (Shirokova dkk., 2017). Pengalaman kewirausahaan, fasilitator, dan orang yang berpengaruh juga dapat berpengaruh pada proses berwirausaha yang dapat dimanfaatkan dalam diri orang tersebut. Salah satu permasalahan utama yang ada di Indonesia pada saat ini adalah pengangguran. Apalagi dengan munculnya wabah covid-19 membuat banyak masyarakat yang di PHK oleh perusahaannya. Pandemi covid-19 membuat ekonomiterpuruk sepanjang 2020. Meski digadanggadang membaik di tahun 2021 ini, namun sejumlah tantangan masih akan terus membayangi pemulihan ekonomi Indonesia. Adapun berdasarkan data Badan Pusat Statistik (BPS), jumlah pengangguran per Agustus 2020 mengalami peningkatan sebanyak 2,67 juta orang. Dengan demikian, jumlah angkatan kerja di Indonesia yang menganggur menjadi sebesar 9,77 juta orang. Oleh karena itu, kita dituntut untuk tidak terlalu mengandalkan pekerjaan dari orang lain. Maka dari itu, menciptakan lapangan pekerjaan sendiri merupakan ide yangbaik dan efektif, sehingga dapat menyerap tenaga kerja yang ada dan dapat meningkatkan roda perekonomian yang akhirnya dapat menurunkan tingkat pengangguran di Indonesia. Berbicara mengenai menciptakan lapangan pekerjaan sendiri, maka kata berwirausaha tentu muncul di benak kita. Wirausaha memiliki peranpenting dalam negara guna meningkatkan pertumbuhan ekonomi dan mengurangi jumlah pengangguran di Indonesia. Wirausahawan berperan baik secara eksternal ataupun internal. Secara eksternal, wirausahawan berperan sebagai penyedia lapangan pekerjaan untuk para pencari kerja. Dengan terserapnya tenaga kerja oleh kesempatankerja yang ada, yang telah disediakan wairausaha, tingkat pengangguran secara nasional akan menjadi lebih berkurang. Dan secara internal, wirausahawan mengurangitingkat ketergantungan kepada orang lain, dapat meningkatkan kepercayaan diri, dan meningkatkan daya beli.

Kewirausahaan dapat mengatasi berbagai masalah perkenomian di Indonesia. Kewirausahaan memiliki peran penting dalam pembangunan ekonomi dan kesejahteraan masyarakat. Rasio kewirausahaan di Indonesia berada di nilai $3.47 \%$ per tahun 2020. Nilai tersebut masih terbilang cukup rendah dibandingkan dengan negara ASEAN lainnya dimana Singapura sudah mencapai nilai $8.47 \%$, Thailand $4.26 \%$, dan Malaysia dengan nilai $4.74 \%$. Kurangnya wirausaha di Indonesia dapat menjadi suatu kelemahan untuk perekonomian di Indonesia, karena wirausaha dapat memberikan kontribusi yang sangat besar bagi perekonomian dan kesejahteraan suatu negara dengan cara meningkatkan lapangan pekerjaan, meningkatkan pemerataan pendapatan, serta memanfaatkan sumberdaya yang ada untuk meningkatkan produktivitas negara. Namun, untuk kesuksesan dari suatu wirausaha dibutuhkan pemikiran yang kreatif. Wirausahaan yang kreatif adalah individu yang memiliki pola pikir wirausaha dalam menanggapi pemicu tindakan wirausaha sendiri. Tindakan wirausaha dibagi menjadi dua, yaitu ekstrinsik dan intrinsik. Tindakan ekstrinsik adalah suatu tindakan yang konstekstual dan didorong oleh bisnis, sedangkan tindakan intrinsik adalah tindakan yang melibatkan keinginan internal untuk menciptakan suatu rasa pencapaian pribadi (Tseng \& Chen, 2021). 
Pelatihan kewirausahaan ini sekiranya dapat membantu masyarakat mengahadapi new normal. Masyarakat dalam hal ini adalah karyawan PT Mandiri Utama Ruslim, yang diharapkan mampu memiliki jiwa wirausaha untuk menghadapi kondisi ini agar mereka dapat "bertahan hidup" pada era new normal ini.

\section{METODE PELAKSANAAN PKM}

Langkah-langkah/Tahapan Pelaksanaan

1. Membuat draft kerangka konsep kewirausahaan berdasarkan para ahli yang ada. Pada bagian ini dilakukan penyuluhan mengenai pentingnya kewirausahaan di era new normal ini dengan menciptakan lapangan pekerjaan untuk membantu para karyawan agar dapat bertahan dan membantu yang lain di masa new normal ini.

2. Menjelaskan sifat dasar dari seorang wirausaha kepada para karyawan PT Mandiri Utama Ruslim. Pada bagian ini dijelaskan mengenai sifat dasar dari seorang wirausaha sehingga dapat disesuaikan dengan karaketeristik dari objek dan dapat diterapkan ilmu tersebut dalam dunia nyata.

\section{HASIL DAN LUARAN YANG DICAPAI}

\section{Profil Usaha}

Nama : PT Mandiri Utama Ruslim.

Wilayah : Villa Melati Mas Blok H9 no. 60 Tangerang

Kecamatan : Serpong Utara

Propinsi : Banten

Jam buka $\quad$ : $08.00-17.00$ (Hari Senin- Sabtu)

PT Mandiri Utama Ruslim merupakan sebuah UMKM yang bergerak pada supplier alat tulis. Perusahaan ini didirikan oleh Willyams dengan tujuan memenuhi kebutuhan alat tulis bagi masyarakat. Perusahaan menyediakan berbagai macam perlengkapan yang pada umumnya di gunakan di dalam kantor yang meliputi produk kertas, alat tulis dan barang dagang. Semua perlengkapan kantor terebut merupakan beberapa perlengkapan kantor yang sangat penting bagi perusahaan, karena kegiatan operasional perusahaan tidak lepas dari perlengkapan kantor seperti pensil, pena, penggaris, buku dan lain sebagainya.
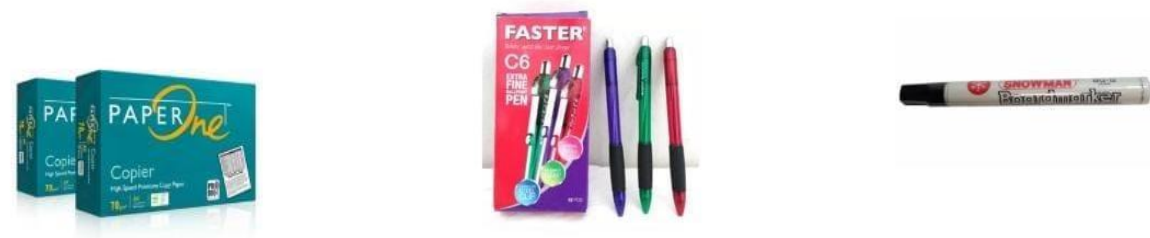

Gambar 1. Alat tulis yang dihasilkan

\section{Pelatihan konsep kewirausahaan}

Pada bagian ini tim memberikan pelatihan dan penyuluhan mengenai konsep dasar kewirausahaan dan bagaimana pengaplikasiannya yang disesuaikan dengan karakteristik objek. Pelatihan yang dimaksud disini adalah memaparkan definisi dari kewirausahaan (Menurut Scarborough, Zimmerer, dan Wilson (2009) wirausaha adalah seorang yang menciptakan bisnis baru dengan mengambil risiko dan ketidakpastian demi mencapai keuntungan dan pertumbuhan yang signifikan dengan cara mengidentifikasi peluang dan menggabungkan sumber-sumber daya yang diperlukan sehingga sumber-sumber daya tersebut dapat dikapitalisasikan), identifikasi dan 
evaluasi peluang (evaluasi peluang, penciptaan dan jangka waktu peluang, nilai riil dan nilai yang dipersepsikan atas peluang, risiko dan pengembalian atas peluang, peluang versus keahlian dan tujuan pribadi, serta lingkungan yang kompetitif). Di samping itu juga menjelaskan faktor pembentuk jiwa wirausaha (Faktor pribadi, terdiri atas motivasional, karakteristik kepribadian dan faktor lingkungan terdiri atas pendidikan, usia, dan pengalaman kerja), serta yang terakhir adalah jenis wirausaha (wirausaha muda, wirausaha perempuan, wirausaha minoritas, wirausaha imigran, wirausaha paruh waktu, Wirausaha rumah tangga, usaha keluarga, wirasutri, wirausaha korban PHK/karyawan yang mengundurkan diri, dan wirausaha sosial)

\section{Sifat-sifat dasar dari seorang wirausaha}

Pada bagian ini tim menjelaskan secara terperinci dan disertai konsep contoh yang relevan mengenai sifat dasar dari seorang wirausaha sehingga dapat disesuaikan dengan karaketeristik dari objek dan dapat diterapkan ilmu tersebut dalam dunia nyata, adapun sifat dasar seorang wirausaha antara lain:

- percaya diri,

- berorientasikan tugas dan hasil,

- berani mengambil risiko, kepemimpinan,

- keorisinilan,

- berorientasi ke masa depan,

- mandiri,

- realistis,

- kreatif dan inovatif,

- fokus tinggi,

- sensitif terhadap perubahan pasar,

- disiplin,

- jujur dan tekun.

\section{KESIMPULAN DAN SARAN}

\section{Kesimpulan}

Berdasarkan pelaksanaan kegiatan Pengabdian Kepada Masyarakat (PKM) ini diperoleh kesimpulan sebagai berikut:

1. PT Mandiri Utama Ruslim merupakan toko alat tulis untuk memenuhi pasar Tangerang dan sekitarnya

2. PT Mandiri Utama Ruslim mengalami masalah dalam hal tenaga kerja yang akan dirumahkan karena efek pandemi.

3. PT Mandiri Utama Ruslim berusaha mengalokasikan pekerjanya kepada bidang atau menjadi wirausaha.

\section{Saran}

\section{Memberikan pelatihan kewirausahaan}

Memberikan pelatihan dan penyuluhan kepada para karyawan yang terdampak pandemi covid19 mengenai konsep dasar kewirausahaan dan bagaimana pengaplikasiannya yang disesuaikan dengan karakteristik objek. Termasuk didalamnya pelatihan mengenai sifat dasar dari seorang wirausaha sehingga dapat disesuaikan dengan karaketeristik dari objek dan dapat diterapkan ilmu tersebut bagi karyawan.

2. Untuk rencana selanjutnya diharapkan dapat membuat business plan atau ide bisnis bagi karyawan 


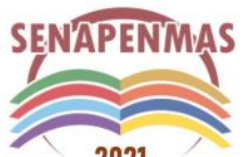

2021
Seminar Nasional Hasil Penelitian dan Pengabdian Kepada Masyarakat 2021

Pengembangan Ekonomi Bangsa Melalui Inovasi Digital Hasil Penelitian dan Pengabdian Kepada Masyarakat Jakarta, 21 Oktober 2021

Pada bagian ini tim menyajikan kepada mitra mengenai proses pembuatan ide bisnis. Adapun tahapan yang digunakan tim adalah memaparkan:

- pengertian dan manfaat analisis kelayakan bisnis,

- manfaat rencana bisnis,

- elemen rencana bisnis,

- format rencana bisnis,

- presentasi rencana bisnis,

- menjelaskan bagaimana investor dan kreditur menilai rencana bisnis.

\section{REFERENSI}

Ajzen, I. (2020). The theory of planned behavior: Frequently asked questions. Human Behavior and Emerging Technologies, 2(4), 314-324.

Marti'ah, S., 2017. Kewirausahaan Berbasis Teknologi (Technopreneurship) dalam Perspektif Ilmu Pendidikan. Jurnal Ilmiah Edutic, 3(2), 75-82.

Mopangga, H., 2015. Studi Kasus Pengembangan Wirausaha Berbasis Teknologi (Technopreneurship) di Provinsi Gorontalo. Trikonomika, [daring] 14(1), hal.13-24. http://www.journal.unpas.ac.id/index.php/trikonomika/article/view/587.

Shirokova, G., Osiyevskyy, O., Morris, M. H., \& Bogatyreva, K. (2017). Expertise, university infrastructure and approaches to new venture creation: Assessing students who start business. Entrepreneurship \& Regional Development, 29(9-10),

Tseng, M., Chen Huei, M. (2021). "Creative entrepreneurs' artistic creativity and entrepreneurial alertness: the guanxi network perspective". International Journal of Entrepreneurial Behaviour \& Research. 
Seminar Nasional Hasil Penelitian dan Pengabdian Kepada Masyarakat 2021

Pengembangan Ekonomi Bangsa Melalui Inovasi Digital Hasil Penelitian dan

Pengabdian Kepada Masyarakat

Jakarta, 21 Oktober 2021

(halaman kosong) 